\title{
USE OF GAUSSIAN MATHEMATICAL MODEL IN THE DISTRIBUTION OF SULPHUR DIOXIDE INTO THE ATMOSPHERE FROM POINT SOURCE
}

\author{
Stevo Jaćimovski, Slobodan Miladinović, Radovan Radovanović, Venezija Ilijazi
}

Original scientific paper

This study analyses the condition and quality of the environment which is endangered by typical pollutants present in urban areas. The main sources of air pollution are power sector (mostly power plants), transport sector (motor vehicles) and industrial plants. Among these substances the most common and most harmful to human health and biological systems is sulphur dioxide. The effects of sulphur dioxide are sensed very easily, most people experience the symptoms after $10 \div 15$ minutes. Therefore the concentration of sulphur dioxide in the air is taken as a referent parameter for the assessment of air quality and evaluation of air pollution. In this study the metallurgy plant which processes 1000 tons of copper-chalcopyrite ore daily is analysed as the illustrative example. By using Gaussian mathematical model the distribution of ground concentration of sulphur dioxide is analysed for the different heights of chimneys and different emissions in stable and unstable atmospheric conditions. Calculation of distribution and spreading of sulphur dioxide covers the period of 24 hours after the release into the atmosphere. The results are compared with the legally permissible limit value concentrations.

Keywords: air pollutant; Gaussian model; point source; sulphur dioxide

\section{Primjena Gausova matematičkog modela kod širenja sumpornog dioksida u atmosferu iz stacionarnog izvora}

Izvorni znanstveni članak

U radu se analizira stanje i kvaliteta okoliša kojeg ugrožavaju postojeći tipični zagađivači urbanih predjela. Glavni izvori zagađenja zraka su sektor energije (uglavnom energane), transporta (motorna vozila) i industrijski pogoni. Među najčešćim i najškodljivijim za ljudsko zdravlje i biološke sustave je sumporni dioksid. Djelovanje sumpornog dioksida osjeća se vrlo lako i većina ljudi osjeća simptome već nakon $10 \div 15$ minuta. Stoga se koncentracija ugljičnog dioksida u zraku uzima kao referentni parameter u procjeni kvalitete zraka i njegovog zagađenja. U radu se kao ilustrativni primjer analizira metalurški pogon koji dnevno prerađuje 1000 tona rude bakra-halkopirita. Primjenom Gausova matematičkog modela analizira se raspodjela koncentracije sumpornog dioksida na zemlji kod dimnjaka raznih visina i različitih količina ispuštanja u stabilnim i nestabilnim vremenskim uvjetima. Distribucija širenje sumpornog dioksida izračunati su za razdoblje od 24 sata nakon ispuštanja u atmosferu. Rezultati su uspoređeni s legalno dopuštenim koncentracijama graničnih vrijednosti.

Ključne riječi: Gausov model; stacionarni izvor; sumporni dioksid; zagađivač zraka

\section{Introduction}

Clean air is hard to define, because it consists of great number of components. It can be considered that the air in its natural condition used to exist about 150 years ago, and today it is practically impossible to be found in nature. It is contaminated by numerous substances caused by human activity. Every alteration in the composition and condition of air which excesses the limits of adaptability of human organism and leads to illnesses is called air pollution. According to air analysis around 3000 of different materials disrupts the natural balance of gasses in atmosphere.

Sources of air pollution can be divided into [1]:

- Natural sources of pollution

- Anthropogenic sources of pollution.

Natural sources of pollution have always been present in biosphere and these include:

- deflation - dispersion of soil and sand (especially increased in the deserts and forest-steppe zones)

- forest and steppe fires smoke (contains CO, soot, pitch, tar and more)

- volcanoes - with strong eruptions they emit huge amounts of dust, gases of $\mathrm{SO}_{2}, \mathrm{CO}_{2}$ etc.

- mineral and thermal springs - they can emit $\mathrm{CO}_{2}$, $\mathrm{H}_{2} \mathrm{~S}$, methane, etc

- cosmic dust, which is believed to be radioactive

- $\quad$ surface of the ocean can be a source of $\mathrm{CO}_{2}, \mathrm{CO}$, $\mathrm{H}_{2} \mathrm{~S}$, chloride etc.
- natural disasters can be accompanied by significant emissions of air pollutants

- storms

- $\quad$ earthquakes. into:

Anthropogenic sources of pollution can be divided

- $\quad$ stationary or point sources

- mobile sources.

Stationary sources of pollution include pollutions in rural areas connected to agricultural activities, mining, stone pits, pollutions caused by industry (chemical, metal, non-metal industry and electricity production) and pollutions in communal areas.

Mobile sources include all vehicles with internal combustion engines.

Up to now hundreds of pollution substances have been identified, and we should certainly point out a possibility of creating new ones, so far unknown compounds, under the influence of solar radiation and electric discharges [2].Typical pollutants include the gases which occur in every urban area and near thermal power plants. The most common pollutants and sources of pollution are given in Tab. 1 .

Air pollution can be transmitted over long distances in relation to the source. Distance depends on the speed of spreading (diffusion) of contaminated air mass and on the speed of sedimentation (deposition) of the contaminated matter. 
Alterations in air polluted by smoke containing components, in the course of the year depend on various factors, such as:

- meteorological conditions

- $\quad$ size of the urban area

- location of measuring point
- chimney heights, temperatures and speed of gasses at the exit of the chimney

- the terrain

- the influence of vegetation, especially forests

- possibilities for self-purification of the atmosphere and

- other physiographical conditions

Table 1 Pollution Substances and Sources of Pollution

\begin{tabular}{|l|l|}
\hline \multicolumn{1}{|c|}{ Pollution substance } & \multicolumn{1}{c|}{ Main source of pollution } \\
\hline Sulphur dioxide $\mathrm{SO}_{2}$ & Combustion of coal, oil, heavy and non-ferrous metallurgy \\
\hline Hydrogen sulphide $\mathrm{H}_{2} \mathrm{~S}$ & Chemical processes, refinery \\
\hline Carbon monoxide $\mathrm{CO}$ & Combustion, engines SUS \\
\hline Oxides of nitrogen $\mathrm{NO}_{\mathrm{x}}$ & Combustion, engines SUS \\
\hline $\mathrm{C}_{\mathrm{n}} \mathrm{H}_{\mathrm{n}+2}$ & Evaporation of liquid fluids, exhaust gases \\
\hline Soot & Combustion \\
\hline Suspended particles & Technological processes, quarry, cement-works \\
\hline Volatile organic compounds & Chemical processes, oil process, distribution of petrol \\
\hline
\end{tabular}

\section{Sulphur dioxide}

It is significant to identify certain kinds of pollutants and their sources. Among these substances the most common and most harmful to human health is sulphur dioxide. A great amount of sulphur dioxide is released from the chimneys of thermal power plants then there are processing of sulphide ore, lead ore, zinc and copper, sulfuric acid, and paper and oil refineries accompanied by other harmful substances.

Sulphur compounds, as a polluting admixtures, emit into the atmosphere:

- natural processes which lead to the emission of sulphur compounds and

- anthropogenic processes which lead to the emission of sulphur compounds.

The emission of the following compounds: $\mathrm{H}_{2} \mathrm{~S}$, $\mathrm{COS}, \mathrm{CS}_{2}, \mathrm{DMS}, \mathrm{SO}_{2}$, various sulphates and mercaptan, comes out of natural systems (atmosphere, biosphere, ocean systems).

Oceans and seas are regarded as the main natural emitters of sulphur dioxide $\left(\mathrm{H}_{2} \mathrm{~S}\right)$. The sources of sulphur dioxide $\left(\mathrm{SO}_{2}\right)$ are oceans and seas, as a result of the oxidation of the emitted sulphur dioxide compounds.

The largest extent of anthropogenic emission of sulphur compounds is through sulphur dioxide. The most important source of sulphur dioxide, appearing in the atmosphere, are plants for burning of fossil fuels, especially coal.

The concentration of sulphur dioxide in the atmosphere in urban and industrial areas is larger than in non-urban area. Generally the production of sulphur dioxide in certain regions is an indicator of the overall level of development and therefore it is not surprising that the total amount of sulphur dioxide that is emitted during the year in an atmosphere of $70 \%$ is in the northern hemisphere.

All the sulphur emitted into the atmosphere returns again to the earth's surface, through sulfuric acid, sulphates and other sulphur compounds. The most controlled are emissions of $\mathrm{SO}_{2}$ of non-cancerous group and soot of cancerous group and complete sedimentary substances. These can be regarded as indicators of air pollution. Sulphur dioxide appears as a product of sulphur combustion in fossil fuels. It is a strong-smelling gas, heavier than air. Its toxicity increases in conditions of increased humidity due to creating sulfuric acid. According to the latest findings, the oxidation products of $\mathrm{SO}_{2}$ in the air are even more toxic than $\mathrm{SO}_{2}$ itself. Soot is produced by burning fossil fuels. These are fine, small particles of about 5 microns. They float in the air and act as a gas. They contain toxic and cancerous substances. Sedimentary substances are particles of solid fuel, ash, road dust which fall on the ground due to their weight. Precipitations with the $\mathrm{pH}$ value beneath 5,6 are called acid precipitations ("acid rains").

Sulphur which is a component of the fuel (coal, oil) burns forming oxides:

$\mathrm{S}+\mathrm{O}_{2}=\mathrm{SO}_{2}$

To a lesser extent further oxidation is implemented:

$\mathrm{SO}_{2}+1 / 2 \mathrm{O}_{2}=\mathrm{SO}_{3}$

Sulphur dioxide and sulphur trioxide accompanied by the suspended particles and humidity have the most harmful effect on humans, living organisms and material goods. These droplets scattered by the wind drop to the ground, which leads to a gradual reduction in its $\mathrm{pH}$ value. Increase of acidification of the ground slows the growth of forests and other plants, and the increase of acidification of water adversely affects the growth of flora and fauna in the waters. As a result of emissions of sulphur dioxide acid rains are formed that have adverse effects on plants, and can also cause corrosion. Sulphur dioxide is a colourless gas which does not burn, whose scent is felt at the concentration in the air of $(0,3 \div 1,0) \times 10^{-6}$, and at the concentration greater than $3 \times 10^{-6}$ sulphur dioxide has a pungent irritating odour. Sulphur dioxide in the mixture with solid particles and sulfuric acid (which has a larger irritating effect than sulphur dioxide) at the average annual concentration of $(0,04 \div 0,9) \times 10^{-6}$ and at the smoke concentration of $150 \div 200 \mu \mathrm{g} / \mathrm{m}^{3}$ leads to the symptoms of impaired breathing and lung disease, and at the average daily concentration of $(0,2 \div 0,5) \times 10^{-6}$ and smoke concentration of $500 \div 700 \mu \mathrm{g} / \mathrm{m}^{3}$ the sudden growth of the diseased and fatal outcomes can be noticed. At the concentration of 
sulphur dioxide of $(0,3 \div 0,5) \times 10^{-6}$ within a few days chronic illness of leaf plants appears (particularly spinach, lettuce, cotton and alfalfa) as well as it appears with needles of conifers.

Sulphur oxides cause acid rains to appear. Chemical reaction which leads to acid rains is given as:

$\mathrm{SO}_{2}+\mathrm{H}_{2} \mathrm{O}=\mathrm{H}_{2} \mathrm{SO}_{3}$ $\mathrm{SO}_{3}+\mathrm{H}_{2} \mathrm{O}=\mathrm{H}_{2} \mathrm{SO}_{4}$.

\section{Gaussian model of distribution of air pollution concentration}

Scattering particles in the atmosphere is related to atmospheric turbulence and is accomplished by molecular and turbulent diffusion [3]. In addition, turbulent diffusion has the essential role while the role of molecular diffusion is negligible. Turbulent diffusion has two components, thermal and dynamic. Thermal diffusion is connected to vertical temperature gradient of air and produces so called convective turbulence. Dynamic diffusion accomplishes mechanical turbulence and is produced during the movement of air masses affected by wind. In the lower layers of troposphere ${ }^{1}$ it is increased under the influence of relief and is not connected to the temperature gradient.

Sources of air pollution of business entities are stationary, when the source coordinates do not change over time and non-stationary such as motor transport. Sources of air pollution can be: point, linear and outdoor. Point sources are the ones which are concentrated on one spot such as chimneys, vents etc. linear sources have distinct length, like highways etc. Outdoor sources are distributed over the surface, such as forest fires. Depending on the height of the hole $(H)$ through which air pollution is emitted, sources can be divided into four classes [3].

Table 2 Calculation parameters

\begin{tabular}{|l|c|c|c|c|c|}
\hline & & $a$ & $b$ & $c$ & $d$ \\
\hline Very unstable & (A) & 0,527 & 0,865 & 0,28 & 0,90 \\
\hline Unstable & (B) & 0,371 & 0,866 & 0,23 & 0,85 \\
\hline Weakly unstable & (C) & 0,209 & 0,897 & 0,22 & 0,80 \\
\hline Neutral & (D) & 0,128 & 0,905 & 0,20 & 0,76 \\
\hline Stable & (E) & 0,098 & 0,902 & 0,15 & 0,73 \\
\hline Very stable & (F) & 0,065 & 0,902 & 0,12 & 0,67 \\
\hline
\end{tabular}

High sources $(H \geq 50 \mathrm{~m})$

Middle sources $(H=10 \div 50 \mathrm{~m})$

Low sources $(H=2 \div 10 \mathrm{~m})$

Ground sources $(H \leq 2 \mathrm{~m})$.

Major part of pollutants is concentrated in the ground layer of atmosphere up to the height of several meters above the earth's surface.

One of the most used models for calculating air pollution is Gaussian air pollution model that comes from stationary sources. In the basis of this model lies an assumption that the pollutants in the atmosphere are distributed according to Gaussian normal distribution.
Similar calculating method is recommended in the USA by the Environmental protection agency and it has a normative character [4].

Models of this type are suitable for both short-term and long-term forecasts of air pollution. Short-term forecasts are executed by a model which calculates the map of pollution for a period of time during which meteorological conditions are stable. The same models can be used for long-term forecasts if the observed time period can be divided into quasi stable meteorological conditions.

This kind of approach may demand certain calculation difficulties, especially when you must determine annual average concentration for a large number of sources of air pollution. The distribution of concentration can be found by direct solving of the equation of turbulent diffusion [5].

According to Gaussian model (Fig. 1) the concentration of light pollutants is determined according to [6]:

$C(x, y, z)=\frac{Q}{2 \pi \sigma_{y} \sigma_{z}} \exp \left\{-\frac{y^{2}}{2 \sigma_{y}^{2}}-\frac{(z-H)^{2}}{2 \sigma_{z}^{2}}\right\}$

where $\sigma_{y}^{2}, \sigma_{z}^{2}$ - dispersions that characterize Gaussian distribution of the axes $y$ and axes $z, Q$ - mass flow of pollutants from stationary source (chimney), $u-$ wind speed, $H$ - effective height of chimney ${ }^{2}$. According to the concrete calculation, dimensions $\sigma_{y}, \sigma_{z}$ (for distances from 100 to $10^{4} \mathrm{~m}$ ) are approximated as follows:

$\sigma_{y}(x)=a x^{b} \sigma_{z}(x)=c x^{d}$

Numbers $a, b, c$ and $d$, are taken from the Tab. 2 [7].

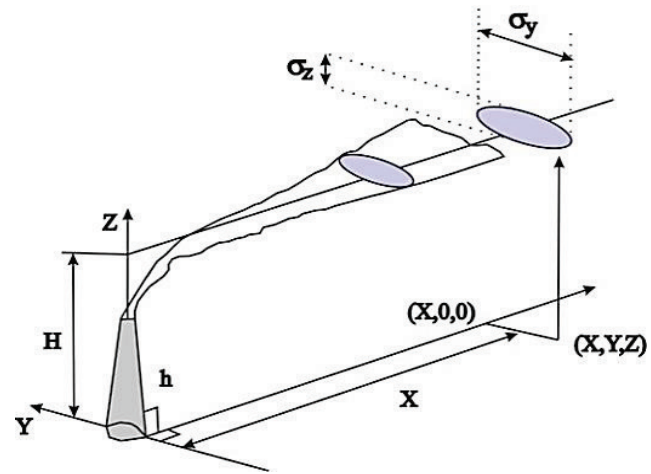

Figure 1 Display of parameters of Gaussian model of pollutants spreading from the source

Gaussian model is an idealization with the following limitations [8]:

1) it can be applied only to flat and open surface

2) it is difficult to include the influence of the obstacles which the smoke column encounters

3) meteorological conditions and conditions of the earth's surface are constant on the whole distance through which the cloud goes

\footnotetext{
${ }^{1}$ Troposphere (up to $11 \mathrm{~km}$ ) - the lowest layer of atmosphere
} 
4) it is applied only to gases with the density close to the density of air

5) it necessarily presupposes the existence of the wind at the speed of $u>1 \mathrm{~m} / \mathrm{s}$.

\section{Illustrative example}

As an example of calculation we can take one metallurgical plant which processes 1000 tons of copperchalcopyrite ore [9]. We shall assume that the atmospheric conditions are neutral and that the wind blows at speed of $3 \mathrm{~m} / \mathrm{s}$ at the height of $10 \mathrm{~m}$. Using the Gaussian model of spreading air pollution we can calculate the distribution of the concentration of sulphur dioxide depending on the height of the chimney for depending on the size of the mass flow for neutral weather conditions as well as the distribution of the concentration depending on different weather conditions.

Releasing $\mathrm{SO}_{2}$ into the atmosphere is a result of technological processing of the ore which is described by the following chemical reaction:

$4 \mathrm{CuFeS}_{2}+11 \mathrm{O}_{2} \rightarrow 4 \mathrm{FeO}+2 \mathrm{Cu}_{2} \mathrm{O}+10 \mathrm{SO}_{2}$

i.e. every 4 moles of ore take 10 moles of gas, which means that 1 mole of ore takes 2,5 moles of gas . Molar mass of ore is $183,52 \mathrm{~g} / \mathrm{mole}$, and molar mass of sulphur dioxide $-64,07 \mathrm{~g} / \mathrm{mole}$. Then you can abstract for one day $2,5 \times 4,07 \times 1000 / 183,52=872,79$ tons or $10101,77 \mathrm{~g} / \mathrm{s}$. Concentration $C$ of released gas will be calculated according to the following formula:

$C(x, 0,0)=\frac{Q}{\pi \sigma_{y} \sigma_{z} u} \exp \left(-\frac{H^{2}}{2 \sigma_{z}^{2}}\right)$,

where we want to know the ground concentration in the direction of the wind blowing, that is the $x$ axis. The wind speed $u$ is determined by the formula [10]:

$u=u_{1} \frac{H}{z_{1}}$,

where $z_{1}=10 \mathrm{~m}, u_{1}$ - wind speed at the height of $10 \mathrm{~m}$. For neutral atmospheric conditions is:

$\sigma_{y}=0,128 x^{0,905}, \sigma_{z}=\alpha \sigma_{y}, \alpha=0,5$

neutral weather conditions. Likewise, we can determine the distribution of the concentration. We want to know the distribution of the ground concentration of $\mathrm{SO}_{2}$ for different heights of chimneys, maximum concentration, distance at which the maximum concentration can be reached, as well as the area in which the concentration of $\mathrm{SO}_{2}$ is above the legally permitted [11].

The results obtained by applying the Gaussian model to a given example are presented in the Tab. 3 and Fig. 2 .
Table 3 Distances of maximum concentrations, limit value of the concentration and the zone in which the concentration is above the limited one

\begin{tabular}{|c|c|c|c|c|}
\hline$H(\mathrm{~m})$ & $x_{\max }(\mathrm{m})$ & $\begin{array}{c}C_{\max } \\
\left(\mathrm{g} / \mathrm{m}^{3}\right)\end{array}$ & $\begin{array}{c}C_{\text {border }} \\
\left(\mathrm{g} / \mathrm{m}^{3}\right)\end{array}$ & $x_{\min } \div x_{\max }(\mathrm{m})$ \\
\hline 50 & 1012,88 & 0,032 & 0,00015 & $257 \div 59218$ \\
\hline 100 & 2463,17 & 0,0039 & 0,00015 & $775 \div 37672$ \\
\hline 150 & 4142,39 & 0,0011 & 0,00015 & $1563 \div 28397$ \\
\hline 200 & 5990,04 & 0,00049 & 0,00015 & $2723 \div 22470$ \\
\hline
\end{tabular}
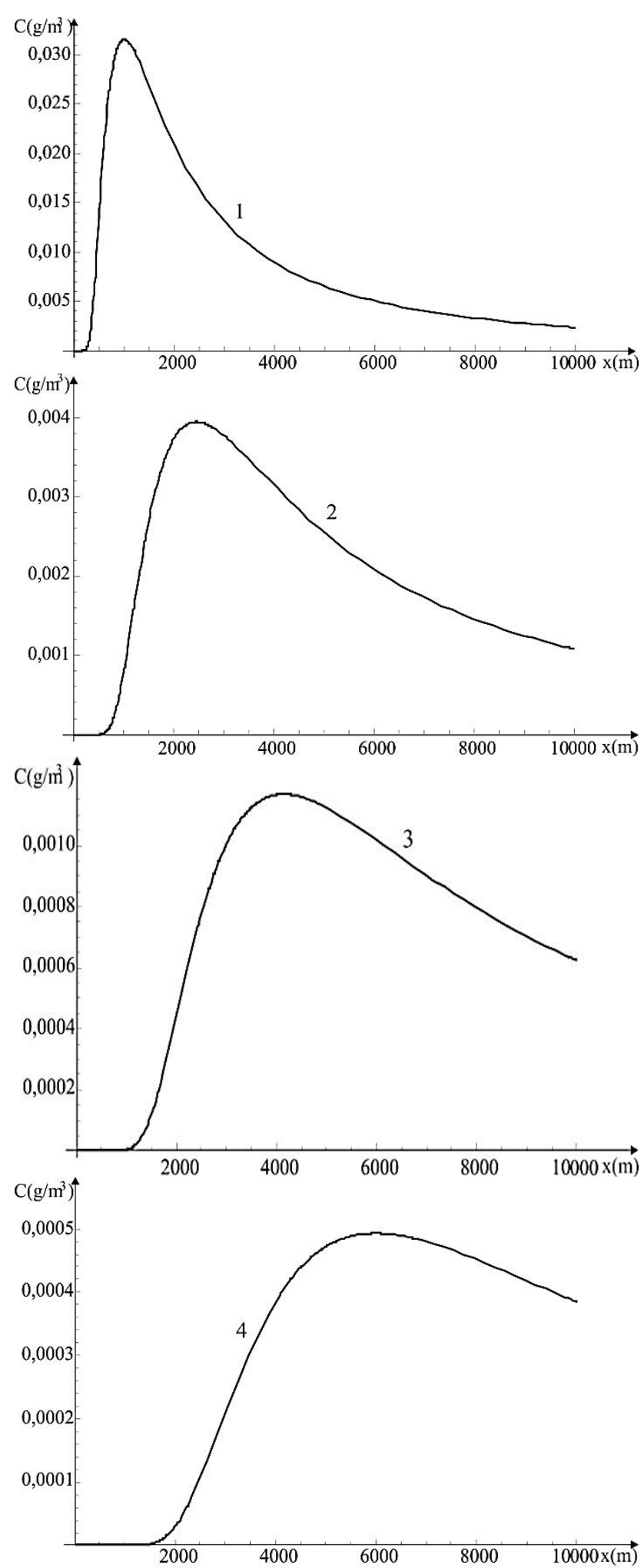

Figure 2 Distribution of concentration in the function of distance from the source for different chimney heights:

1) $H=30 \mathrm{~m}, 2) H=100 \mathrm{~m}, 3) H=150 \mathrm{~m}, 4) H=200 \mathrm{~m}$ 
Also, the analysis of the concentration dependence on the distance for different mass source flows and for different meteorological conditions. Concentration dependence on the distance for different mass source flows is presented in Fig. 4.

Dependence of the concentration of the air pollution on the distance of the source for different meteorological conditions is presented in Fig. 5.

All calculations were performed by the software package Mathematica 9.

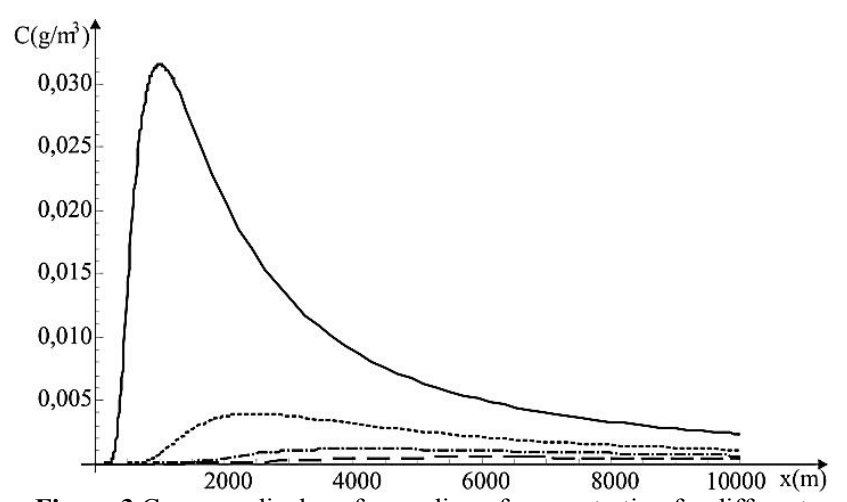

Figure 3 Common display of spreading of concentration for different chimney heights:

1) $H=50 \mathrm{~m}$, 2) $H=100 \mathrm{~m}, 3) H=150 \mathrm{~m}, 4) H=200 \mathrm{~m}$

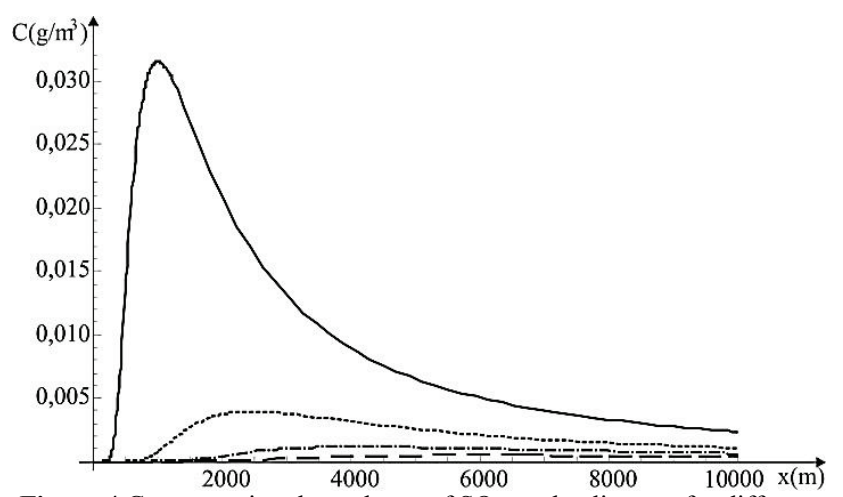

Figure 4 Concentration dependence of $\mathrm{SO}_{2}$ on the distance for different source flows and for the same chimney height-blue line corresponds to

the source power 1,5 times greater than the basic (red line), and the

black line corresponds to the source power 2 times greater than the basic

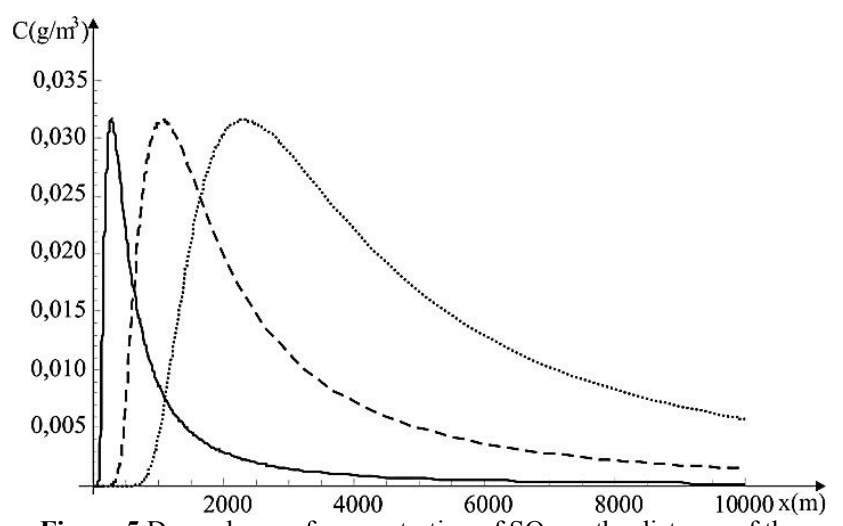

Figure 5 Dependence of concentration of $\mathrm{SO}_{2}$ on the distance of the source for different weather conditions-black line corresponds to unstable conditions, blue to the neutral and red to the stable ones

\section{Conclusion}

This study has analysed one of the most common air pollutants, and that is sulphur dioxide which comes into the atmosphere either by combustion of different fuels or procession of ores in industrial units. Spreading of sulphur dioxide into the atmosphere during the processing of copper-chalcopyrite ore was taken as an example which illustrated the use of Gaussian model for calculating air pollution and finding the ground concentration in the situation of stable weather conditions. Although every model necessarily stands for appropriate simplifications, it is obvious that mathematical moulding of pollutant's spreading into the atmosphere can be calculated relatively fast (up to 24 hours), assessment of spreading and the size of the concentration thereof. Calculations were made for different heights of stationary point source (chimney). Also, it can be estimated at what distance the maximum concentration will be and what its value will be. Besides, you can find a zone in which the concentration is above the legally permitted.

The given example shows that the lower the height of the chimney is, the bigger the ground concentration becomes. Also, the pollutant concentration is above the limited in the wider area as the height of the chimney gets lower. With the increase of the chimney height, maximum concentration is shifted to larger distances from the chimneys and at the same time the concentration maximums have a lower value.

Fig. 5 shows that the larger the mass source flow gets, the greater the maximum concentration value gets, and concentration maximums are moving away from the source. Fig. 6 clearly shows that maximum values of concentration do not depend on weather conditions. Also, for bad weather conditions the concentration maximums are implemented closer to the source of the pollution.

In further research these mathematical models could be implemented into actual systems, and with the data obtained by monitoring the specific area near the source of the pollution and with the use of the Geographic information system, the concentration and direction of spreading of gaseous substances is obtained in relation to geotopographic content which was used for the analysis, and the coverage area. Further analysis may focus on assessing the impact in relation to the categories of land and populated areas. In that way a powerful weapon for prevention and analysis of spreading harmful substances could be obtained, which would help improve the quality of life in certain areas.

\section{Acknowledgement}

This paper is partly financed by the Ministry of Education and Science of Republic of Serbia, Project TR34019

\section{References}

[1] Tiwary, A.; Colls, J. Air Pollution, Routledge, New York, 2010.

[2] Jaćimovski, S.; Miladinović, S.; Ilijazi, V.; Zorić, V. M.; Šetrajčić I. J.; Armaković, S.; Šetrajčić J. P. Linear Expansion of Air Pollution. // The $2^{\text {nd }}$ International Conference Ecology of Urban Areas, Proceedings / Zrenjanin (2012), pp. 62-67

[3] Берлянд, М. Е. Прогноз и регулирование загрязнения атмосферы, Гидрометеоиздат, Ленинград, 1985. 
[4] Lazaridis, M. First principles of Meteorology and Air Pollutant, Springer, New York, 2011. DOI: 10.1007/978-94007-0162-5

[5] Tošić, B. S.; Stojanović, S. D.; Škrinjar, M. J.; Kapor, D. V. The one dimensional problem of air-pollutant distribution, Faculty of Sciences-University of Novi Sad. // Review of Research. Vol. 12, (1982), pp. 61-65.

[6] Cranck, J. C. The Mathematics of Diffusion, Clarendon Press, Ofxord, 1975.

[7] Pasquill, F.; Smith, F. B. Atmospheric Diffusion, J. Wiley \& Sons, New York, 1982.

[8] Sportisse, B. Fundamentals in Air Pollution, Springer, New York, 2008.

[9] Tasić, V.; Milivojević, D.; Pavlov, M. Air Quality Control in Bor (Theory and Practice). // Bakar. 32, 2(2007), pp. 216.

[10] Степаненко, С. Н.; Волошин. В. Г.; Типцов, С. В. Решение уравнения турбулентной диффузии для стационарного точечного источника. // Украинский гидрометеоро-логический журнал. 3 (2008), ст. 13-25.

\section{Authors addresses}

dr Stevo Jaćimovski

Academy of Criminalistic and Police Studies, Belgrade Cara Dušana 196 11080 Zemun, Serbia stevo.jacimovski@kpa.edu.rs

dr Slobodan Miladinović

Academy of Criminalistic and Police Studies, Belgrade Cara Dušana 196

11080 Zemun, Serbia

slobodan.miladinovic@kpa.edu.rs

dr Radovan Radovanović

Academy of Criminalistic and Police Studies, Belgrade Cara Dušana 196

11080 Zemun, Serbia

radovan.radovanovic@kpa.edu.rs

\section{dipl. ing. Venezija Ilijazi}

The Ministry of Internal Affairs of the Republic of Serbia, Belgrade

Kneza Miloša 101

11000 Belgrade, Serbia

venezija.ilijazi@mup.gov.rs 